\title{
PERGESERAN KLASIFIKASI IKLIM OLDEMAN DAN SCHMIDTH-FERGUSSON SEBAGAI DASAR PENGELOLAAN SUMBERDAYA ALAM DI BENGKULU
}

\author{
Anang Anwar ${ }^{1}$, Sigit Sudjatmiko ${ }^{2}$, Muhammad Faiz Barchia ${ }^{3}$ \\ ${ }^{1}$ Stasiun Klimatologi Bengkulu, Jl. Ir. Rustandi Sugianto Pulau Baai Bengkulu. \\ ${ }^{2,3}$ Agroekotek, Jl. WR. Supratman Kandang Limun, Bengkulu 38371 A, Indonesia. \\ Telp/Fax +62-736-21170/+62-736-22105 \\ 1 ananganwar77@gmail.com
}

\begin{abstract}
Abstrak
Perubahan pola hujan, pergeseran musim, kenaikan suhu merupakan dampak dari perubahan iklim. Perubahan pola hujan ini akan mempengaruhi system klasifikasi Schmidth-Ferguson dan Oldeman. Jumlah Bulan basah, bulan lembab dan bulan kering menjadi penentu dalam penentuan system klasifikasi Schmidth-Ferguson dan Oldeman. Provinsi Bengkulu mempuanyai pola hujan equatorial dengan dua puncak hujan di bulan November dan Januari dan hujan paling sedikit pada bulan Juni. Tipe iklim oldeman yang di miliki adalah tipe iklim A1, B1, C1 dan Tipe iklim Schmidth Ferguson A, B, C dan D (Sangat Basah, Basah, Agak Basah dan Sedang). Pergeseran tipe iklim Oldeman yang terjadi adalah pergeseran luasan, Tipe iklim A1 yang dominan bergeser luasan nya terdistribusi ke tipe iklim B1 dan $\mathrm{C} 1$ untuk daerah yang bergeser adalah hampir semua wilayah Bengkulu kecuali kab. Seluma. Tipe iklim Schmidth Ferguson bergeser dari A yang dominan bergeser ke tipe iklim A, B, C dan D, daerah yang mengalami pergeseran adalah wilayah Bengkulu bagian selatan. Proyeksi untuk tipe iklim Schmidth-Ferguson dan Oldeman tipe iklim yang mengalami perubahan adalah tipe iklim oldeman
\end{abstract}

Kata kunci: iklim oldeman, iklim Schmidth-Fergusson,Curah Hujan, Proyeksi

\section{PENDAHULUAN}

\section{Latar Belakang}

Perubahan iklim menyebabkan terjadinya perubahan pola hujan, pergeseran musim, kenaikan suhu, dan kenaikan muka air laut.Salah satu dampak perubahan iklim di sektor pertanian yaitu kegagalan panen akibat kejadian iklim ekstrim semakin sering terjadi dan semakin meluas (Boer, et al. 2015). Informasi cuaca yang selalu yang terkini (up to date), bimbingan teknis kepada petani agar lebih baik lagi mengelola resiko iklim dan mengurangi dampak ekonomi dari perubahan iklim seperti kebanjiran atau kekeringan, peningkatan dan pengembangan pemodelan iklim untuk membuat gambaran iklim pada masa yang akan datang.

Peta klasifikasi iklim Oldeman dan Schmidth-FergussonBengkulu yang telah dibuat oleh Stasiun Klimatologi Bengkulu perlu di perbaharui dengan pertimbangan kejadian hujan yang terjadi selama ini. Peta klasifikasi iklim selama ini belum ada yang di publikasikan, padahal di Bengkulu mempunyai potensi sumberdaya alam yang sangat besar. Berdasarkan hal tersebut perlu dilakukan penelitian dan pemetaan pergeseran klasifikasi iklim Oldeman dan Schmidth-Fergusson sebagai upaya pemanfaatan sumberdaya bidang klimatologi dalam pengelolaan 
sumberdaya alam di Bengkulu. Tujuan dalam penelitian ini adalah membuat peta up-dating dan pergesaran klasifikasi klasifikasi iklim Oldeman periode 20 dan 30 tahun Propinsi Bengkulu serta pergeseran sampai dengan tahun 2040. Hasil penelitian ini diharapkan dapat memberikan manfaat akan tersedianya peta terupdate klasifikasi iklim Oldeman dan peta klasifikasi iklim Schmidth-Fergusson, Pengambil kebijakan dapat menjadikannya sebagai bahan pertimbangan dalam menyusun rencana pembangunan di Bengkulu.

\section{BAHAN DAN METODE}

\section{Lokasi, Pengumpulan dan Analisis Data}

Penelitian ini dilakukan di wilayah provinsi Bengkulu. Metode pengumpulan data pada penelitian ini dengan cara menginventarisir data curah hujan periode 20 tahun dan 30 tahun selama tahun 1971 sampai dengan 2010. Metode analisis yang digunakan dalam penelitian ini adalah metode mean (ratarata hitung) yaitu jumlah semua nilai data dibagi banyaknya data, rata-rata hitung disimbolkan sebagai $\bar{x}$ (dibaca $x$ bar). Rumus mean (rata-rata hitung) dari data tunggal sebagai :

$\bar{x}=\frac{1}{n}\left(x_{1}+x_{2}+x_{3}+\cdots . .+x_{n}\right)$

atau $\bar{x}=\frac{\sum x_{1}}{n}$

Data yang dihitung rata-ratanya adalah data curah hujan setiap pos yang Tabel 1. Interpretasi agroklimat oldeman mempunyai series data lebih dari 10 tahun.

\section{Sistem Klasifikasi Oldeman}

Oldeman dalam Bayong (1999) menyatakan Jumlah curah hujan sebesar $200 \mathrm{~mm}$ tiap bulan dipandang cukup untuk membudidayakan padi sawah, sedangkan untuk tanaman palawija maka jumlah curah hujan minimal yang di perlukan $100 \mathrm{~mm}$ tiap bulan. Oldeman et al, (1980) membagi lima zona iklim dan lima sub zona iklim. Zona iklim merupakan pembagian dari banyaknya jumlah bulan basah berturutturut yang terjadi dalam setahun, sedangkan sub zona iklim merupakan banyaknya jumlah bulan kering berturut-turut dalam setahun. Pemberian nama Zone iklim berdasarkan huruf yaitu zone $\mathrm{A}$, zone $\mathrm{B}$, zone $\mathrm{C}$, zone $\mathrm{D}$ dan zone $\mathrm{E}$, sedangkan pemberian nama sub zone berdasarkan angka yaitu sub 1 , sub 2, sub 3 sub 4 dan sub 5 . Berdasarkan penelitian Oldeman maka di buat tabel interpretasi klasifikasi Oldeman dengan tujuan untuk memudahkan dalam penerapan di lapangan.

\section{Sistem Klasifikasi Schmidth- Fergusson}

Sistem iklim SchmidthFergusson merupakan penyempurnaan dari metode Mohr. Schmidth-Fergusson (1951) dalam Bayong (1999) menghitung jumlah bulan kering dan

\begin{tabular}{|c|c|}
\hline Tipe Iklim & Penjabaran \\
\hline $\mathrm{A} 1, \mathrm{~A} 2$ & $\begin{array}{l}\text { Sesuai untuk padi terus menerus tetapi produksi kurang karena pada umumnya kerapatan fluks radiasi } \\
\text { surya rendah sepanjang tahun }\end{array}$ \\
\hline $\mathrm{B} 1$ & Musim tanam yang baik produksi tinggi bila panen musim kemarau \\
\hline $\mathrm{B} 2$ & $\begin{array}{l}\text { Dapat tanam yang dua kali setahun dengan varietas umur pendek dan musim kering yang pendek untuk } \\
\text { tanam palawija }\end{array}$ \\
\hline C1 & Tanam padi dapat sekali dan palawija dua setahun \\
\hline $\mathrm{C} 2, \mathrm{C} 3$ & $\begin{array}{l}\text { Tanam padi dapat sekali dan palawija dua kali setahun, tetapi penanaman palawija yang kedua harus hati- } \\
\text { hati jangan jatuh pada bulan kering }\end{array}$ \\
\hline D1 & $\begin{array}{l}\text { Tanam padu umur pendek satu kali dan biasanya produksi tinggi karena kerapatan fluks radiasi tinggi } \\
\text { waktu tanam palawija }\end{array}$ \\
\hline $\mathrm{D} 2, \mathrm{D} 3, \mathrm{D} 4$ & Hanya mungkin satu kali padi dan satu kali palawija setahun tergantung pada adanya persediaan air irigasi \\
\hline E & Daerah ini umumnya terlalu kering, mungkin hanya dapat satu kali palawija, itupun tergantung hujan \\
\hline
\end{tabular}


bulan basah dari tiap-tiap tahun kemudian baru diambil rata-ratanya. Data yang di gunakan lebih dari 10 tahun dari dari stasiun pos pengamatan curah hujan.Untuk menentukan jenis iklim Schmidth-Fergusson menggunakan harga perbandingan $\mathrm{Q}$ yang di definisikan sebagai :

$\mathrm{Q}=\frac{\text { Jumlah rata }- \text { rata bulan kering }}{\text { Jumlah rata }- \text { rata bulan basah }}$

Bulan kering merupakan jumlah curah hujan yang turun dan sampai kepermukaan bumi mempunyai jumlah curah hujan < $60 \mathrm{~mm}$. Bulan lembab adalah jumlah curah hujan yang sampai ke permukaan antara 60 sampai dengan $100 \mathrm{~mm}$, dan bulan basah adalah jumlah hujan yang turun dan sampai keperumakaan bumi lebih dari 100 (Lakitan 2002). Berdasarkan Penelitiannya, Schmidth-Fergusson membagi penggolong iklim di Indonesia menjadi 8 (delapan) golongan (tabel 2).

\section{Suhu rata-rata menurut teori Lapsrate}

Suhu udara merupakan derajat panas dan dingin suatu keadaan yang dipengaruhi oleh sinar matahari. Suhu udara akan menurun dengan bertambahnya ketinggian tempat. Setiap ketinggian bertambah 100 meter, suhu udara berkurang (turun) rata-rata $0,6^{\circ} \mathrm{C}$. Penurunan ini disebut gradient temperatur vertikal atau lapse rate. Pada udara kering, besar lapse rate adalah $1{ }^{\circ} \mathrm{C}$ (Lakitan , 2002).

Tabel 2. Klasifikasi Schmidth Ferguson

\begin{tabular}{l|l|l}
\hline \multicolumn{1}{c|}{ Tipe Iklim } & \multicolumn{1}{c}{ Kriteria } & \multicolumn{1}{c}{ Kriteria } \\
\hline A. (Sangat Basah) & Hutanhujan tropika & $0<\mathrm{Q}<0.143$ \\
B. (Basah) & Hutanhujan tropika & $0.143<\mathrm{Q}<0.333$ \\
C. (Agak Basah) & Hutan rimba & $0.333<\mathrm{Q}<0.600$ \\
D. (Sedang) & Hutan musim & $0.600<\mathrm{Q}<1.000$ \\
E. (Agak Kering) & Hutan sabana & $1.000<\mathrm{Q}<1.670$ \\
F. (Kering) & Hutan sabana & $1.670<\mathrm{Q}<3.000$ \\
G. (Sangat Kering) & Padang ilalang & $3.000<\mathrm{Q}<7.000$ \\
H. (LuarBiasaKering) & Padang ilalang & $7.000<\mathrm{Q}$ \\
\hline
\end{tabular}

\section{WRF (Weather Research and Forecasting)}

Weather Research and Forecasting (WRF) adalah generasi masa depan dari model cuaca yang dapat digunakan untuk melakukan prediksi atmosfer skala menengah dan mengasimilasikan hasil prediksi tersebut dengan data observasi local. WRF dikembangkan oleh The Mesoscale and Microscale Meteorology Division of NCAR, di Boulder, Colorado. Model cuaca WRF ini sangat cocok untuk dikembangkan sebagai pemodelan cuaca mendasar di Indonesia karena telah digunakan sebagai dasar prediksi oleh seluruh konstituen yang terkait dengan prediksi cuaca

\section{Diagram Alir Pengolahan Data}

Untuk penentuan tipe iklim oldeman maupun Schmidt-Ferguson maka harus menentukan titik koordinat pos curah hujan, kumpulkan data pos hujan dengan series data lebih dari 10 tahun. Tentukan klasifikasi Oldeman dengan membandingkan bulan basah dan bulan kering berdasarkan segitiga Oldeman, dan klasifikasi Schmidth-Fergusson dengan mencari nilai Q. Buat daftar pos hujan berdasarkan titik koordinat lintang dan bujur serta klasifikasi Oldeman dan Schmidth-Fergusson dalam sebuah tabel untuk keperluan pemetaan, lakukan pembuatan peta (analisa spasial) dengan menggunakan aplikasi Arc GIS dengan metode Interpolasi IDW (Inverse Distance 
Weighted), untuk menentukan pergeseran klasifikasi Oldeman dan Schmidth-Fergusson dengan membandingkan luasan tipe iklim yang telah di interpolasi dengan tools yang ada yaitu calculate geometri. Lakukan interpretasi terhadap klasifikasi Oldeman dan Schmidth-Fergusson untuk memudahkan dalam mengaplikasikan di lapangan.

\section{HASIL DAN PEMBAHASAN}

\section{Updating klasifikasi iklim} oldemanperiode 20 tahun (periode 1991-2010) dan periode 30 tahun (periode 1981-2010)
Berdasarkan hasil perhitungan updating klasifikasi iklim oldeman untuk periode 20 tahunan (1991-2010) dan periode 30 tahun $(1981-2010)$, di ketahui bahwa di propinsi Bengkulu memiliki 3 kelas iklim oldeman antara lain: A1, B1 dan C1, terlihat gambar1.

\section{Pergesaran tipe iklim Oldeman periode 20 tahun dan 30 tahun}

Tipe iklim Oldeman di Bengkulu periode 20 tahunan, terlihat perbedaan yang cukup signifikan periode tahun 1971-1990 dan periode 1991-2010 untuk wilayah Bengkulu Utara, Mukomuko dan Lebong hal ini terjadi karena distribusi pos hujan di wilayah tersebut sangat sedikit.

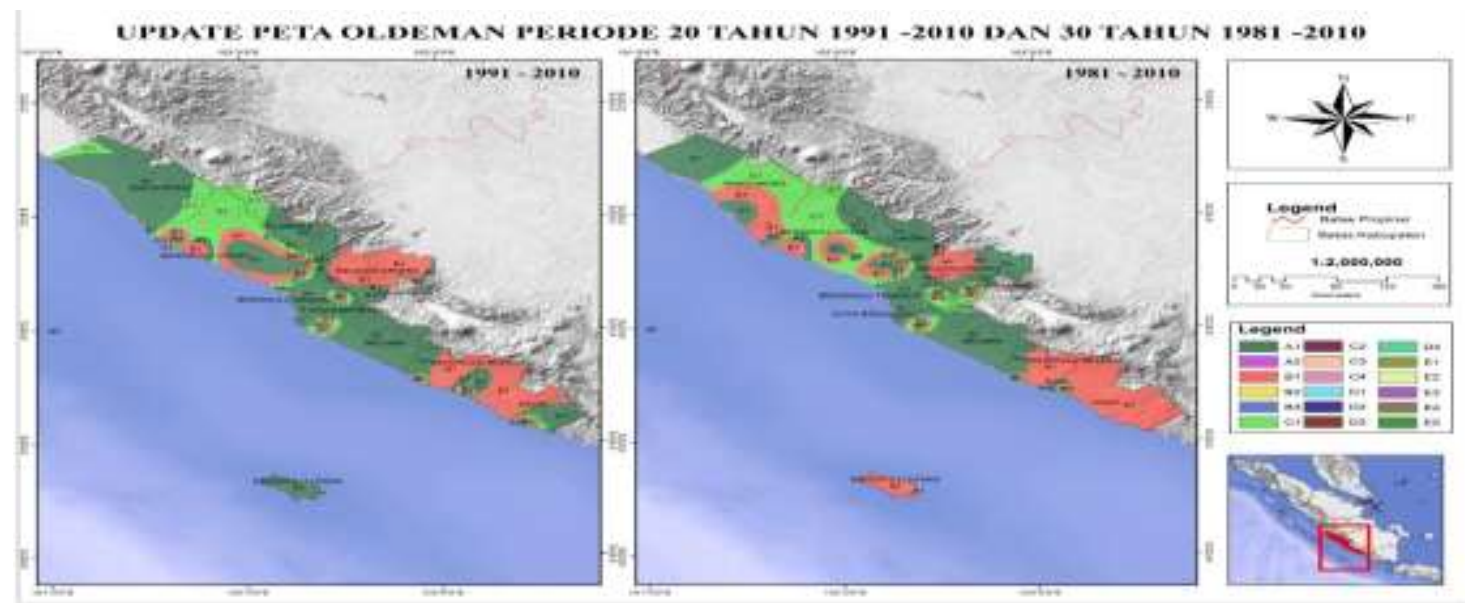

Gambar 1. Update Peta Oldeman Periode 20 tahun dan 30 tahun

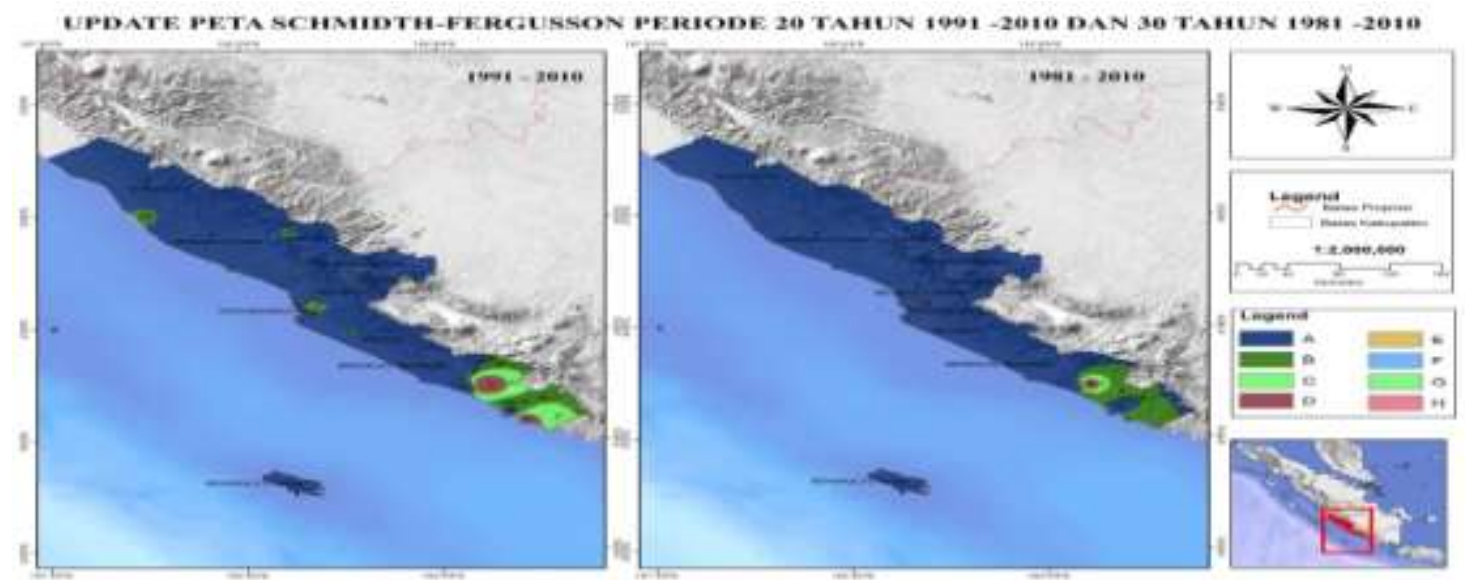

Gambar 2. Update Peta Schmidth-Ferguson periode 20 tahun dan 30 tahun 
Periode 30 tahun klasifikasi Oldeman mengalami pergeseran, wilayah tipe iklim A1 mengalami pergeseran yang cukup signifikan.Luasan wilayah A1 yang dominan pada periode tahun 1971-2000 terdistribusi ke tipe iklim B1 dan C1, pada periode 1981-2010 provinsi Bengkulu mengalami peningkatan luas wilayah pada tipe iklim B1.
Pergesaran tipe iklim SchmidthFerguson Periode 20 tahunan dan 30 tahunan

Pergesaran klasifikasiSchmith Ferguson di Bengkulu periode 20 tahun dan 30 tahun mengalami pergeseran, tipe iklim A mengalami pergesaran yang cukup signifikan terutama untuk wilayah Bengkulu Selatan dan Kaur. Kondisi serupa dengan periode 30 tahun.

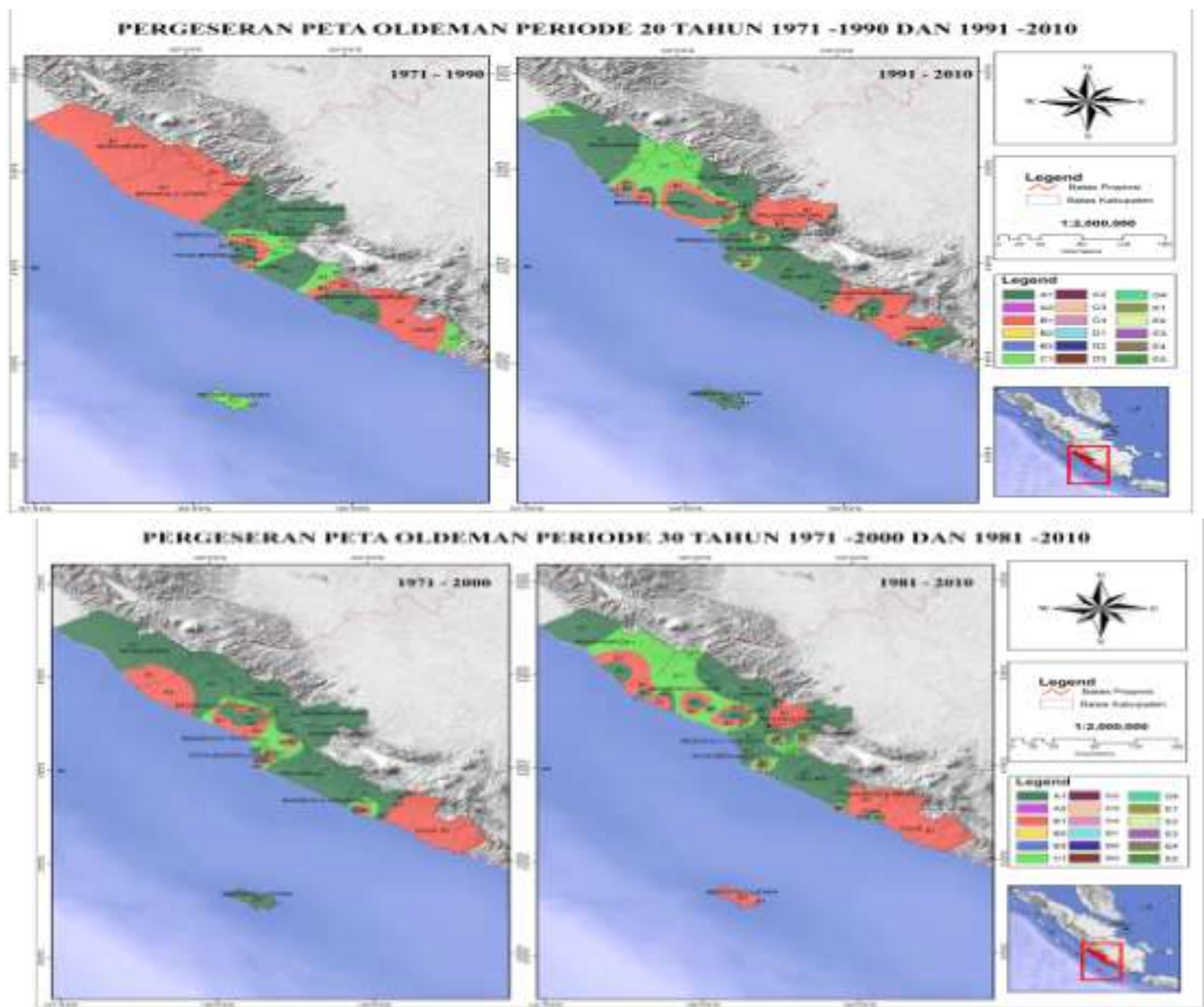

Gambar 3. Peta Pergesearan tipe oldeman tahunan periode 20 tahun dan 30 tahun 

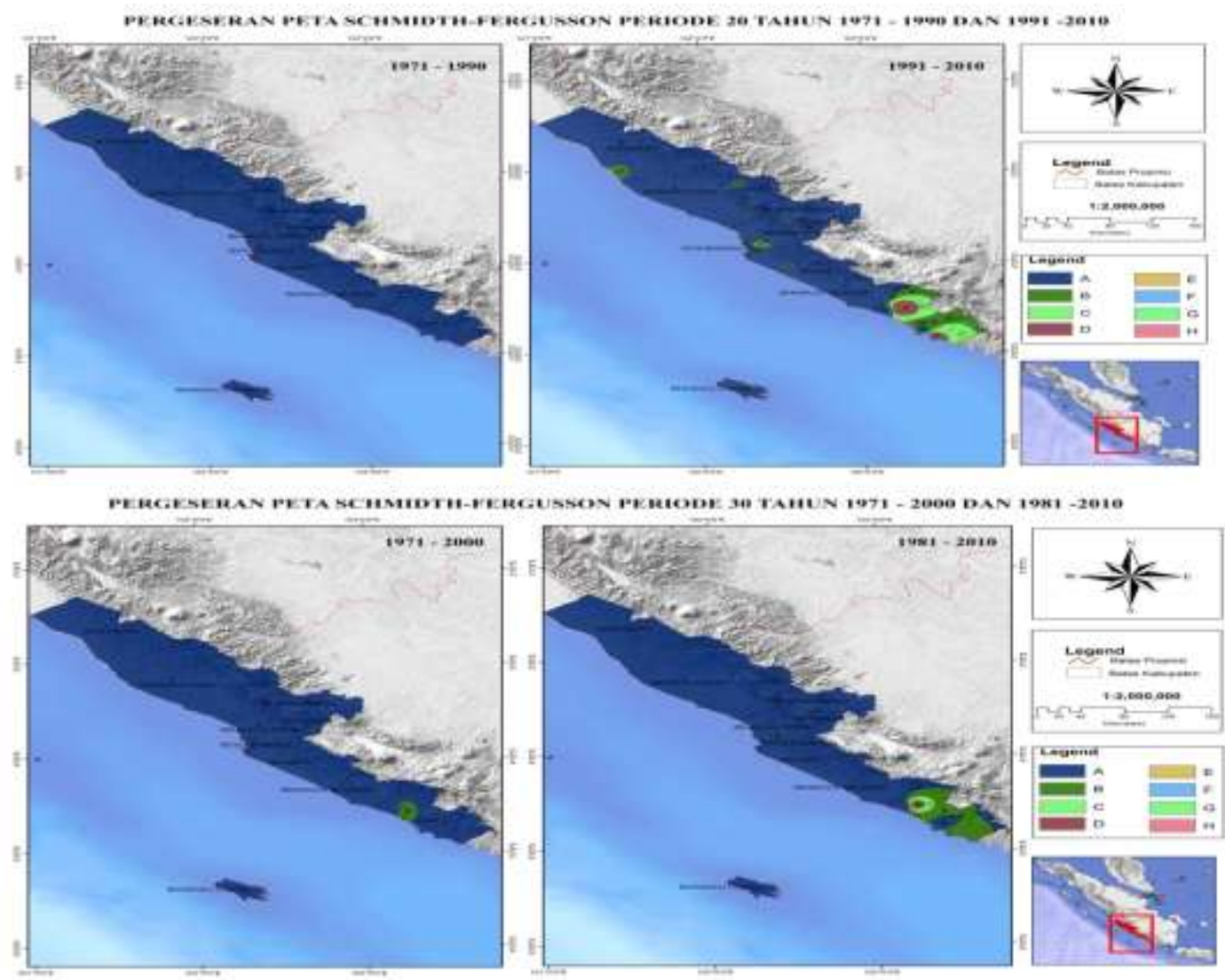

Gambar 4. Peta Pergeseran Schmith-Ferguson tahunan periode 20 tahun dan 30 tahun

\section{Proyeksi klasifikasi Oldeman dan Schmith-Ferguson (2017-2040)}

Analisa spasial proyeksi klasifikasi Oldeman sampai dengan tahun 2040 dengan menggunakan metode IDW di propinsi Bengkulu. Tipe iklim C3 lebih dominan dengan luas wilayah2.414,19 $\mathrm{Km}^{2}$, berarti di wilayah Bengkulu akan mengalami pengurangan curah hujan. Analisa spasial proyeksi tipe iklim Schmidth-Ferguson sampai dengan tahun 2040 dengan menggunakan metode IDW di propinsi Bengkulu Tipe iklim A mendominasi untuk wilayah kabupaten Mukomuko, Bengkulu Utara, Lebong, Rejang Lebong, Kepahiang, Bengkulu Tengah, dan Kota Bengkulu, seperti terlihat gambar 5
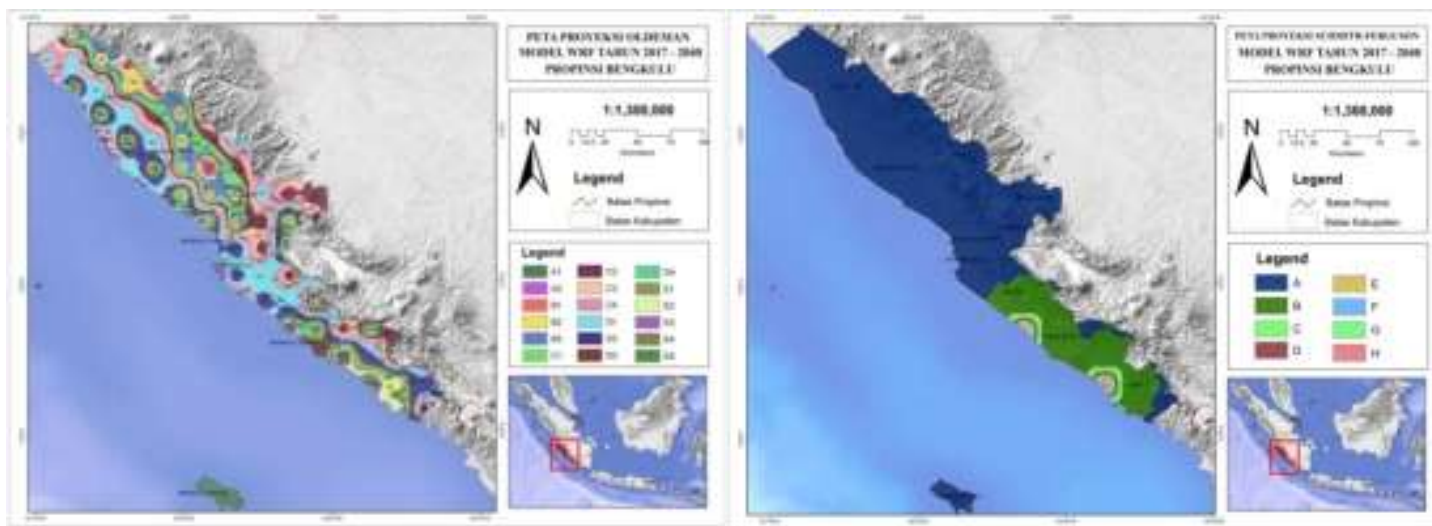

Gambar 5. Peta Proyeksi Oldeman dan Schmidth-Ferguson WRF tahun 2017 - 2040 
Interpretasi Keterkaitan Oldeman dan Schmidth-Ferguson

Updating Keterkaitan oldeman dan schmidth ferguson menurut peta ferguson dan Oldeman periode 30 tahun (19812010), informasi ini dapat memberikan penjelasan tentang hubungan vegetasiyang paling dominan serta aktivitas tanam padi oleh masyarakat petani wilayah kabupaten/kota Bengkulu umumnya memiliki vegetasi Hutan Hujan Tropika, dengan interpretasi agroklimat oldeman yang beragam. Kabupaten Bengkulu Selatan, Kaur dan sebagian Benkulu Utara dan Kepahiang memiliki karakteristik agroklimat dapat ditanam padi secara terus menerus dengan perencanaan awal musim tanam yang baik dan produksi tinggi pada musim kemarau. Wilayah kabupaten Bengkulu Tengah dan sebagian Mukomuko, Bengkulu Utara memiliki karakteristik sesuai untuk tanam padi sekali dan palawija dua kali setahun. Kota Bengkulu, kabupaten Lebong, Rejang Lebong, Seluma dan sebagian wilayah Mukomuko dan Kepahyang memiliki karakteristik agroklimat tanam padi secara terus menerus tetapi produksi nya kurang karena kerapatan fluks radiasi surya yang rendah sepanjang tahunProyeksi Keterkaitan Oldeman dan Schmid Ferguson periode 30 tahun 20182040 umumnya di wilayah propinsi

Tabel 3. Interpretasi Keterkaitan Oldeman dan Schmidth-Ferguson periode 30 tahun (1981-2010)

\begin{tabular}{|c|c|c|c|c|}
\hline No. & $\begin{array}{c}\text { Wilayah } \\
\text { Kabupaten }\end{array}$ & $\begin{array}{l}\text { Suhu } \\
\left({ }^{\circ} \mathbf{C}\right)\end{array}$ & Vegetasi & Intrepretasi agroklimat Oldeman \\
\hline 1 & $\begin{array}{l}\text { Bengkulu } \\
\text { Selatan }\end{array}$ & $25-26$ & $\begin{array}{l}\text { Hutan Hujan } \\
\text { Tropika }\end{array}$ & $\begin{array}{l}\text { Sesuai untuk padi terus menerus dengan perencanaan awal } \\
\text { musim tanam yang baik produksi tinggi bila panen musim } \\
\text { kemarau }\end{array}$ \\
\hline 2 & $\begin{array}{l}\text { Bengkulu } \\
\text { Tengah }\end{array}$ & $20-26$ & $\begin{array}{l}\text { Hutan Hujan } \\
\text { Tropika }\end{array}$ & Tanam padi dapat sekali dan palawija dua kali setahun \\
\hline 3 & $\begin{array}{l}\text { Bengkulu } \\
\text { Utara }\end{array}$ & $21-26$ & $\begin{array}{l}\text { Hutan Hujan } \\
\text { Tropika }\end{array}$ & $\begin{array}{l}\text { Tanam padi dapat sekali dan palawija dua kali setahun, dan } \\
\text { sebagian wilayah Sesuai untuk padi terus menerus dengan } \\
\text { perencanaan awal musim tanam yang baik produksi tinggi } \\
\text { bila panen musim kemarau }\end{array}$ \\
\hline 4 & Kaur & $24-26$ & $\begin{array}{l}\text { Hutan Hujan } \\
\text { Tropika }\end{array}$ & $\begin{array}{l}\text { Sesuai untuk padi terus menerus dengan perencanaan awal } \\
\text { musim tanam yang baik produksi tinggi bila panen musim } \\
\text { kemarau }\end{array}$ \\
\hline 5 & Kepahiang & $19-24$ & $\begin{array}{l}\text { Hutan Hujan } \\
\text { Tropika }\end{array}$ & $\begin{array}{l}\text { Sesuai untuk padi terus menerus tetapi produksi kurang } \\
\text { karena pada umumnya kerapatan fluks radiasi surya rendah } \\
\text { sepanjang tahun dan sebagian wilayah Sesuai untuk padi } \\
\text { terus menerus dengan perencanaan awal musim tanam yang } \\
\text { baik produksi tinggi bila panen musim kemarau }\end{array}$ \\
\hline 6 & Bengkulu & 26 & $\begin{array}{l}\text { Hutan Hujan } \\
\text { Tropika }\end{array}$ & $\begin{array}{l}\text { Sesuai untuk padi terus menerus tetapi produksi kurang } \\
\text { karena pada umumnya kerapatan fluks radiasi surya rendah } \\
\text { sepanjang tahun }\end{array}$ \\
\hline 7 & Lebong & $19-24$ & $\begin{array}{l}\text { Hutan Hujan } \\
\text { Tropika }\end{array}$ & $\begin{array}{l}\text { Sesuai untuk padi terus menerus tetapi produksi kurang } \\
\text { karena pada umumnya kerapatan fluks radiasi surya rendah } \\
\text { sepanjang tahun }\end{array}$ \\
\hline 8 & Mukomuko & $24-26$ & $\begin{array}{l}\text { Hutan Hujan } \\
\text { Tropika }\end{array}$ & $\begin{array}{l}\text { Sesuai untuk padi terus menerus tetapi produksi kurang } \\
\text { karena pada umumnya kerapatan fluks radiasi surya rendah } \\
\text { sepanjang tahun dan sebagian wilayah sesuai untuk Tanam } \\
\text { padi dapat sekali dan palawija dua kali setahun }\end{array}$ \\
\hline 9 & $\begin{array}{l}\text { Rejang } \\
\text { Lebong }\end{array}$ & $19-24$ & $\begin{array}{l}\text { Hutan Hujan } \\
\text { Tropika }\end{array}$ & $\begin{array}{l}\text { Sesuai untuk padi terus menerus tetapi produksi kurang } \\
\text { karena pada umumnya kerapatan fluks radiasi surya rendah } \\
\text { sepanjang tahun }\end{array}$ \\
\hline 10 & Seluma & $23-26$ & $\begin{array}{l}\text { Hutan Hujan } \\
\text { Tropika }\end{array}$ & $\begin{array}{l}\text { Sesuai untuk padi terus menerus tetapi produksi kurang } \\
\text { karena pada umumnya kerapatan fluks radiasi surya rendah } \\
\text { sepanjang tahun }\end{array}$ \\
\hline
\end{tabular}


Bengkulu memiliki vegetasi hutan hujan tropika tetapi untuk luasan daerah yang memiliki hutan hujan tropika berkurang terjadi padakabupaten Bengkulu Selatan, Kaur, dan Seluma .

Intrepretasi agroklimat di wilayah Propinsi Bengkulu di ambil dari persentasi terbesar yang ada di wilayah tersebut, kabupaten Bengkulu Selatan $20,6 \%$ dan $16.8 \%$ wilayah kabupaten Kaur hanya mungkin satu kali padi atau satu kali palawija setahun tergantung fluks radiasi tinggi waktu tanam palawija. Bengkulu Tengah22.1\%, Kepahiang $16,1 \%$ dan Rejang Lebong 30,7\% dapat di tanam tanaman padi sekali dan palawija dua kali setahun, tetapi penanaman palawija yang kedua harus hati-hati jatuh pada bulan kering. Wilayah Bengkulu Utara 17,9\% dan Lebong 24,7\% dapat di tanam padi dapat sekali dan palawija dua kali setahun. Wilayah Kabupaten Mukomuko 21,6\% dan Seluma $46,3 \%$ cocok untuk tanaman padi umur pendek satu kali dan biasanya produksi bisa tinggi karena kerapatan fluks radiasi tinggi waktu tanam palawija. Kota Bengkulu 44,2 \% wilayah nya hanya mungkin satu kali padi atau satu kali palawija setahun tergantung pada adanya persediaan air irigasi.

\section{KESIMPULAN}

1. Up date tipe iklim oldeman periode 20 tahun umumnya bergeser dari tipe iklim B1 menjadi A1 dan C1, luasan tipe iklim B1 berkurang yang semula $12.000 \mathrm{Km} 2$ menjadi $5.000 \mathrm{Km} 2$ dan selisih nya terdistribusi ke tipe iklim A1 dan C1, untuk tipe iklim SchmidthFergusson wilayah Bengkulu umumnya memiliki tipe iklim A dengan luasan sekitar $17.500 \mathrm{~km} 2$ dari seluruh luas wilayah propinsi Bengkulu $24.500 \mathrm{~km} 2$, selanjut tipe iklim B, C dan D

2. Pergeseran tipe iklim Oldeman periode 30 tahun berbeda dari periode 20 tahun, Pergesaran yang tejadi tipe iklim A1 yang semula $13.500 \mathrm{Km} 2$ bergeser menjadi $9.000 \mathrm{Km} 2$ dan terdistribuis ke tipe iklim B1 dan $\mathrm{C} 1$, sedangkan pola pergeseran tipe iklim Schmith-Ferguson periode 20 tahun dan 30 tahun mempunyai pola yang sama, tipe iklim A bergeser luasannya bergerser ke tipe iklim B, C dan D, daerah kabupaten yang banyak terjadi pergeseran terjadi di kabupaten Kaur.

3. Proyeksi menggunakan model WRF sampai dengan tahun 2040, tipe iklim oldeman di propinsi Bengkulu bervariasi dengan dominasi pola tipe iklim D, untuk tipe iklim SchmidthFergusson umumnya mempunyai tipe iklim A, daerah yang mengalami perubahan yaitu kabupaten Kaur, Bengkulu Selatan dan Seluma menjadi tipe iklim $\mathrm{B}$ hingga $\mathrm{H}$

4. Keterkaitan Oldeman dan SchmidthFerguson periode 30 tahun 1981- 2010, umumnya di Bengkulu mempunyai hujan tropis dengan menanam padi secara terus menerus dengan menggunakan perencanaan awal musim tanam yang baik, kecuali untuk daerah sebagian Bengkulu Tengah dan Bengkulu Utara menanam padi dapat di lakukan sekali dengan palawija dua kali dengan suhu antara $19-26{ }^{\circ} \mathrm{C}$.

5. Proyeksi keterkaitan Oldeman dan Schmidth-Ferguson dengan menggunakan WRF bahwa hutan hujan tropis makin berkurang dan wilayah untuk menanam padi semakin berkurang dengan penanam padi dapat di lakukan sekali

\section{REFERENSI}

Aldrian, E.,2001. Pembagian iklim Indonesia berdasarkan pola curah hujan dengan metode double correlation. Jurnal Sains dan Teknologi Modifikasi Cuaca1(2): 113-123 
As-syakur, A. R., I. W. Nuarsa,I. W., and Sunarta, I. N.,2010. Pemutakhiranpeta agroklimat klasifikasi Oldeman di pulau Lombok dengan aplikasi sistem informasi geografis updating agroklomate map base in Oldeman classification at Lombok island using. Penelitian Masalah Lingkungan di Indonesia

As-syakur, Abd Rahman, et al. 2011. Pemetaan kesesuaian iklim tanaman pakan serta kerentanannya terhadap perubahan iklim dengan sistem informasi geografi (SIG) di Provinsi Bali. Pastura: Jurnal Ilmu Tumbuhan Pakan Ternak 1.(1); 915.

Badan Pusat Statistik Propinsi Bengkulu, 2015. Bengkulu Dalam Angka 2015. BPS Propinsi Bengkulu. Bengkulu

Bayong, 1999, Klimatologi Umum, Bandung, ITB.

Boer, R., Perdinan, F. A., Amanah, S., A., 2015. Kerentanan Dan Pengelolaan Risiko Iklim Pada Sektor Pertanian, Sumberdaya Air \& Sumber Kehidupan Masyarakat Nusa Tenggara Timur, UNDP-SPARC Project. Kementerian Lingkungan Hidup dan Kehutanan. Jakarta

ESRI, and C. A. Redlands. 2004. ArcGIS. New York

Gatot, H.P., 2008.Akurasi metode IDW dan Kriging untuk interpolasi sebaran sedimen tersuspensi di Maros, Sulawesi Selatan.
Irwansyah, E.,2013. Sistem informasi geografis: prinsip dasar dan pengembangan aplikasi. DigiBook Yogyakarta, Jogyakarta

Lakitan, B., 2002. Dasar-dasar Klimatologi. RajaGrafindo Persada. Jakarta

Oldeman, L. R., and Frere, M., 1982 Technical Report on a Study of the Agroclimatology of the Humid Tropics of Southeast Asia. Food \& Agriculture Org

Pasaribu, J. M., and Haryani.N. S.,2012. Perbandingan Teknik Interpolasi DEM SRTM dengan Metode Inverse Distance Weighted (IDW), Natural Neighbor, dan Spline." $J$ Pengindraan Jauh 9.(2): 126-139.

Puntodewo,A., Dewi, S., and Tarigan.J., 2003 "SIG Untuk Pengelolaan Sumberdaya Alam.". Center for International Forestry Research. Jakarta

Sasminto, A. R, and Sutanhaji, A.T., 2014Analisis Spasial Penentuan Iklim Menurut Klasifikasi SchmidtFerguson dan Oldeman di Kabupaten Ponorogo." Jurnal Sumber Daya Alam dan Lingkungan 1.(1): 51-56.

Sipayung, S. B., Lely Q. A., and Bambang D. D., 2010. Analisis pola curah hujan indonesia berbasis luaran model sirkulasi global (GCM). Jurnal Sains Dirgantara 4(2)

Tjasyono, B. 1999. Klimatologi Umum. ITB Press. Bandung 